\title{
Minulost a budoucnost česko-slovenské komparatistiky
}

\author{
Miloš Zelenka (České Budějovice)
}

Dne 9. 5. 2016 se na Pedagogické fakultě Jihočeské univerzity v Českých Budějovicích pod záštitou Katedry slovanských jazyků a literatur a Česko-slovenské asociace srovnávací literární vědy (slovensky Česko-slovenská asociácia porovnávacej literárnej vedy - ČSAPLV) konal mezinárodní seminář pod názvem Minulost a budoucnost česko-slovenské komparatistiky. Přítomni byli členové předsednictva ČSAPLV (doplněni Márií Bátorovou a Petrem Kučerou), kteří tohoto badatelského setkání využili nejen k odbornému dialogu, ale i k pracovnímu zasedání, jehož cílem se stalo zhodnocení dosavadní činnosti a př́íprava účasti na XXI. kongresu Mezinárodní asociace pro srovnávací literaturu (ICLA/AILC) ve Vídni v červenci 2016. Spolu s tím bylo vymezeno předběžné téma druhé konference ČSAPLV pod názvem Národni kultury středni Evropy z pohledu literární komparatistiky plánované s mezinárodní účastí pravděpodobně na podzim 2017. Českobudějovický seminář se měl pro předsednictvo ČSAPLV stát zároveň příležitostí zamyslet se nad směřováním komparatistických studií v našich zemích, napřr. zda existují perspektivy společného výzkumu a zda lze nalézt témata, která by spojila různorodé aktivity členů Asociace? Dále: čím se můžeme prezentovat v světové komparatistické komunitě, jaké podněty ve srovnávací literární vědě v návaznosti na domácí tradice lze využít?

Jednání zahájil příspěvek Róberta Gáfrika (Bratislava - Trnava) Slovenská komparatistika v 21. storoči, který ve svém přehledu detailně zmapoval institucionální publikační a personální vývoj slovenské literární vědy v „postd'urišinovském“ období reprezentovaný zejména ediční činností Ústavu svetovej literatúry SAV v Bratislavě, kde má sídlo úspěšně se rozvíjející Česko-slovenská asociace srovnávací literární vědy. Podle přednášejícího je zde zřejmý odklon od historické poetiky a Ďurišinovy teorie mezi- literárnosti směrem k teorii kulturních identit, k postkoloniálním výzkumům a areálovým studiím s důrazem na střední a jihovýchodní Evropu. Komparatistika zde sice ztrácí svůj teoretický status a „čistotu“ metody, zároveň však proniká do jiných oborů jako specificky epistemologická perspektiva výzkumu. Mária Bátorová (Bratislava) ve svém vystoupení Spoločný projekt česko-slovenskej komparatistiky (idea, návrh) promluvila o své literárněvědné metodě realizované v monografii o Tatarkovi, která slovenského spisovatele interpretuje na pozadí evropských literárních i mimoliterárních souvislostí. Komparatistika by si měla klást i otázky, jak psát inovativně národní literární dějiny, zahrnující např. i vývoj kulturních institucí. Představila také návrh společného česko-slovenského projektu: reinterpretovat texty z obou literatur, které znamenaly historický a estetický přelom ve vzájemných vztazích. Petr Kučera (Plzeň) v příspěvku Základni problémy interkulturni komparatistiky přiblížil průniky současné filozofie a literární vědy: světový filozofický kongres v jihokorejském Soulu 2012 akceptoval interkulturní studia v americkém pojetí. Proti tomuto „pohybu“ se však staví kultura dialogu hlásaná mysliteli židovského původu (J. Derrida, J. Kristeva, E. Levinas ad.). Ti i přes svou metafyzičnost „tvář jiného“ chápou jako problém hermeneutiky, nikoli jako otázku direktivního multikulturalismu založeného na aditivní komparaci uzavřených fenoménů. Anton Pokrivčák (Trnava) v návaznosti na předchozí vystoupení charakterizoval v referátu Kultúrno-estetické dominanty $v$ anglickom a slovenskom romantizme americký multikulturalismus, který v literárněvědné praxi údajně nepřinesl očekávané výsledky, zmínil rovněž i zprávu od badatele Hauna Saussyho o stavu komparatistických studií, která svou koncepcí interdisciplinárního diskursu se odrazila na amerických školách, kde se již běžně vykládají autoři píšící ,jiným“ než 
anglickým jazykem. Jestliže se od dob R. Wellka mluví o krizi komparatistiky, je třeba respektovat fakt, že největší teoretické impulsy literární vědě jako takové přinesli právě srovnávací literární vědci. Pokrivčák na příkladu středoevropské romantiky zdůraznil nutnost vykládat tyto autory ve vztahu k Byronovi, který byl populárnější mimo svůj anglosaský kontext ve východní a stř̌ední Evropě. Miloš Zelenka (Praha - České Budějovice) ve své úvaze Komparatistika mezi vědou a uměním upozornil na dvě protikladné tendence ve vývoji světové srovnávací literární vědy: jde o institucionalizovaný univerzitní obor s přesnými algoritmy racionálně komponovaných fenoménů anebo o intuitivní vcitovací aktivitu podobnou reprodukčnímu umění? Je možné ve srovnávacích studiích absolutně negovat kategorii „národního“, pokud nemáme adekvátní sémantickou a terminologickou náhradu (podobně tomu bylo u kdysi odmítaného pojmu „vliv“, který se znovu - nejen v slovenské literární vědě - vrací zpět do běžného užívání)? Anebo se pokusit o pochopení „nadnárodního“ prostřednictvím „národního“? Možnou odpověd' lze hledat v hybridním průniku obou extrémů: moderní komparatistika znamená samostatně modelovaný pohled na svět pohybující se na průsečíku polymorfních a vzájemně nesouvislých lokusů literatury a kultury. Komparatistika zároveň směřuje nejen do oblasti konstrukce „makrocelkü“ (D. Ďurišin), ale i do sféry marginalizované ,jinakosti“, tj. do mikrokultur, jako jsou např. literatury národnostních, ale i sexuálních menšin.

Následující diskuse, která volně přešla $\mathrm{v}$ zasedání předsednictva ČSAPLV, se poté vrátila k hledání ideální podoby budoucích srovnávacích studií, které paradoxně mají své historické kořeny $\mathrm{v}$ genezi národních literatur na počátku romantického hnutí. V této souvislosti M. Bátorová zdůraznila potřebu studovat „plovoucí“ identitu tzv. malých kultur z hlediska jejich blízkosti se světovým literárním procesem, a to pod zorným úhlem možných průniků; např. položit si otázku, co nás spojuje s nositeli Nobelovy ceny za literaturu. Debata zároveň potvrdila potřebu stanovit srovnávací literární vědě i přes její tematické i oborové rozšíření jisté mantinely, které lze vymezit aspekty kultury, interdisciplinarity, internacionalizace, zejména však binární opozicí „nadnárodni““ a „národni““. Závěrem předseda Asociace R. Gáfrik ocenil úsilí I. Pospísila a A. Zelenkové při sestavování monotematického čísla Slavica litteraria (1/2015), v němž byly publikovány referáty z prvního setkání ČSAPLV z Bratislavy 2015. Dále informoval o př́ípravě panelu na XXI. kongresu ICLA/ AILC ve Vídni s názvem Old and New Conceptsof Comparative Literature in the Globalized World, na němž vystoupí čeští a slovenští komparatisté (M. Bátorová, R. Gáfrik, P. Kučera, I. Pospíśil, D. Pucherová, L. Vajdová, M. Zelenka) spolu se zahraničními kolegy (Marko Juvan, Adam F. Kola, Dorota Kołodziejczyk, Andrei Terai, Galin Tihanov ad.). Celkově lze shrnout, že česko-slovenská komparatistika díky Asociaci, jejíž postavení má být potvrzeno na vídeňském kongresu přijetím za kolektivního člena ICLA/AILC, nabírá „druhý dech“ svou internacionalizací, tj. vědomým úsilím vyrovnat se se světovými trendy.

E-mail: zelenka@pf.jcu.cz 